\title{
On "Long-Run-Transitions" in Urban Planning Supported by More Advanced Geothermal Energy Utilization in City of Nis, Serbia
}

\author{
Aleksandar Jovanović, TU Graz
}

\begin{abstract}
In order to give reasons for further advanced multi-faceted research of geothermal utilization, geothermal energy utilization and its integration in urban planning in the long run in the City of Nis were analysed. Regional aspect of this utilization is considered, which is novelty in the planning of the city. The arguments are supported by expert opinions on geothermal utilization acquired abroad and in Serbia that suggest geothermal use within proposals for an eco-city.
\end{abstract}

Keywords - City of Nis, geothermal energy, local resource, sustainable planning, urban development.

Introduction. Importance of Planning Geothermal Energy in the Regional Context

Geothermal energy utilization is one of the cleanest renewable energies on the Earth. It offers a way, how a city, building or sets of building can cut-down emissions caused by heating and cooling appliances which are mostly based on fossil fuel use and external energy sources, meaning the energy needed for their utilization is produced at another location and is being transported to the location of the building of where it is used.

Many cities worldwide, e.g Reykjavik, Paris, a few smaller towns in Austria, Germany and Slovakia, etc., have adopted geothermal heating option within a district. Geothermal planning is an important tool in sustainable development as it can help stabilizing the energy supply [20] and work in synergy with other renewable sources to enable transformations and urban revival of cities [27]. Lastly, it could help to develop a long-term strategy in urban planning. The possible implications of the effects of geothermal urban planning have not been vastly examined so far.

The Republic of Serbia is a country in South East of Europe (SEE) and is a country in transition, meaning that it is moving towards market economy and dealing with its politics and issues regarding spatial and urban planning [17] and realizing the need for its historical and local urban and rural heritage preservation, as a tool for sustainable projects. Although its history is somewhat different from other post-communist countries in Europe, it shares similar post-socialism heritage in urban planning with the Eastern bloc countries (referred to usually in general as Eastern Europe). This allows for a general cross-reference of the results of scientific studies and approaches in science from many countries in Europe, countries in the Baltics being among those. The purpose of this paper is an in-depth analysis of Serbian city of Nis (in the South East of Serbia) and its geothermal potential for urban planning in transition to a more sustainable city with a locally harnessed geothermal resource as a tool of urban revival and regional cohesion.

\section{Methodology and Structure of the Paper}

For the analysis of these possibilities, the post-industrial situation of urban morphology in the city of Nis was explained and geothermal resources in the city of Nis were addressed by referencing literature sources and the inclusion of Geothermal Energy (GE) into General urbanistic plans (related to Serbian law on spatial planning as GUPs). The city's past and current urban planning strategical decisions are analysed and criticized from the aspect of local sustainable planning. The paper shows how the affirmation of sustainable and community-based urban planning of a city may be assisted by a more profound geothermal energy utilization. Additionally, a set of interview statements from several experts acquired in Serbia and abroad, within the scientific method of expert interview, is mentioned. Lastly, concrete physical location of the sources within the city and recommendations for further means of their integration in urban planning are given, proposing the next steps, in conclusion.

\section{Planning in Nis}

The city of Nis, being at the crossroads throughout its history, originates from the pre-historic times. It was named by Scordischi, probably the original founders of the city (279 BC), and later renamed several times by the Romans (Naissus), the Byzantines (Nisa), Ancient Greeks (Navissos), Turks (Nish), Serbians (Niš) [9]. It has acquired many different influences, was part of many empires and for centuries has been a strong fortified centre in South Eastern Europe. Origins of many different tribes had been found in the archaeological excavations. Its position on the route (via Militaris in Roman Empire) and later regional Orient Express way contributed to its importance from the antique onwards. It has secured its position as a strong transitional centre through its history and has finally become a centre of industry and education in the $20^{\text {th }}$ century in Serbia. Nis was a strategically important industrial city of Serbia (and Yugoslavia) comprising electronics, machine industry as well as other primary industries. Unfortunately, Balkan wars at the end of the $20^{\text {th }}$ century, the fall of the Iron Curtain and transitional changes made it one of the poorest of large Serbian cities. Unemployment in the industry, no investments, being away from the prosperous northern capital 


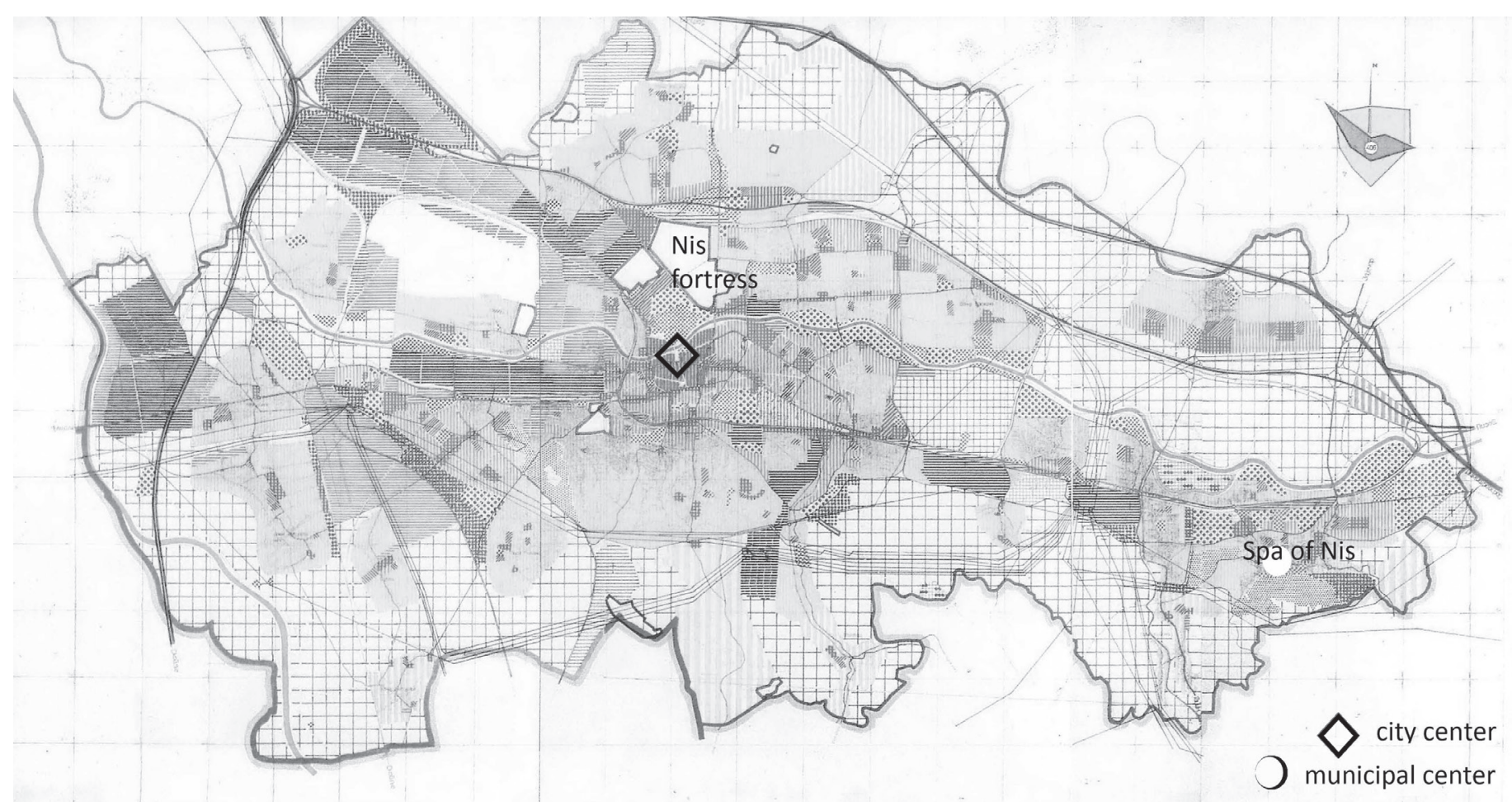

Fig. 1. General Urban Planning document of Nis 1995-2010, focused on anything but utilization of geothermal resources [Figure: Zavod za Urbanizam, Niš. Calendar, 2011].

regions and its near cities, gave way to a new transitional, "freemarket"-based appearance of Nis and its urban design, to much of the dislike by the citizens and its planners. Nis is known as the city of unfinished urbanization [11], meaning that the majority of urban planning strategies have not been fulfilled as scheduled and that a lot of city parts contain only fragments of urbanistic plans, that tackled the development of the whole city and its neighbourhoods. This also means uncontrolled urban development, more power to economic benefit of the investors and low capability of citizens in governing the urban expansion of their own city.

On the other hand, the necessity for some sort of organized and planned approach to natural (geothermal) potentials "utilization has proven to be necessary" [16]. In the case of Nis and its described semi-controlled 'free market' development, utilization of geothermal resources would also need to be informed by strategic decisions of planners and governing bodies, as the carriers of sustainable city development.

Current urban planning instruments in Nis are suggested in the general urban planning document of Nis, GUP 2010-2025 [22]. Several other general urbanistic plans were developed before, but none of them considered opportunities arising by more extensive geothermal planning as an urban planning tool. With the declining role of urban planning, this is slowly going to change. The urban planning authorities in Nis emphasized such elements as the position of church in the 1990s and 2000s (Fig. 1), which is arguable not as important as the defining of geothermal resources supply spots, that could further relate to demand in energy of various city parts [12]. It seems that Nis, like many other cities worldwide, was growing depending on external energy supply for most of its infrastructure. At the dawn of the new energy crisis and arising policies of green movement, geothermal utilization in Nis seems like an option worth considering even if only as an option for a long-term city-energy-transition and despite its current unfavourable socio-political situation. In the next chapters, some arguments for and against geothermal prospects for Nis shall be given.

\section{Geothermal Energy Potentials and Utilization in Serbian Cities}

Serbia has mostly low enthalpy geothermal potential that is being used mostly for balneology and tourism to a modest extent [1]. However, in the recent decades, there has been an increase in geothermal utilization in Serbia, for agriculture and other organized uses. Based on the results from an interview with a geothermal expert based in Serbia, there is a great potential for Southern Serbia, where also Nis belongs to. They just haven't found proper use yet [3]. In whole of Serbia, couple of most significant examples of geothermal utilization can be found in Vranjska Spa [24], followed by Debrc, Kucura and Srbobran [14]. Recent geothermal utilization projects for towns include those at Bogatic [25] and Ljig. Nis is left behind in explorations on energy transition with renewable sources, although it is in greatest need of energy transition than ever and local government still does not realize the value of these examinations [8]. Some recent studies on energy efficiency which have suggested using geothermal for buildings have mostly been focused on the city of Belgrade [26]. Despite these valuable suggestions, "the use of geothermal for industry 


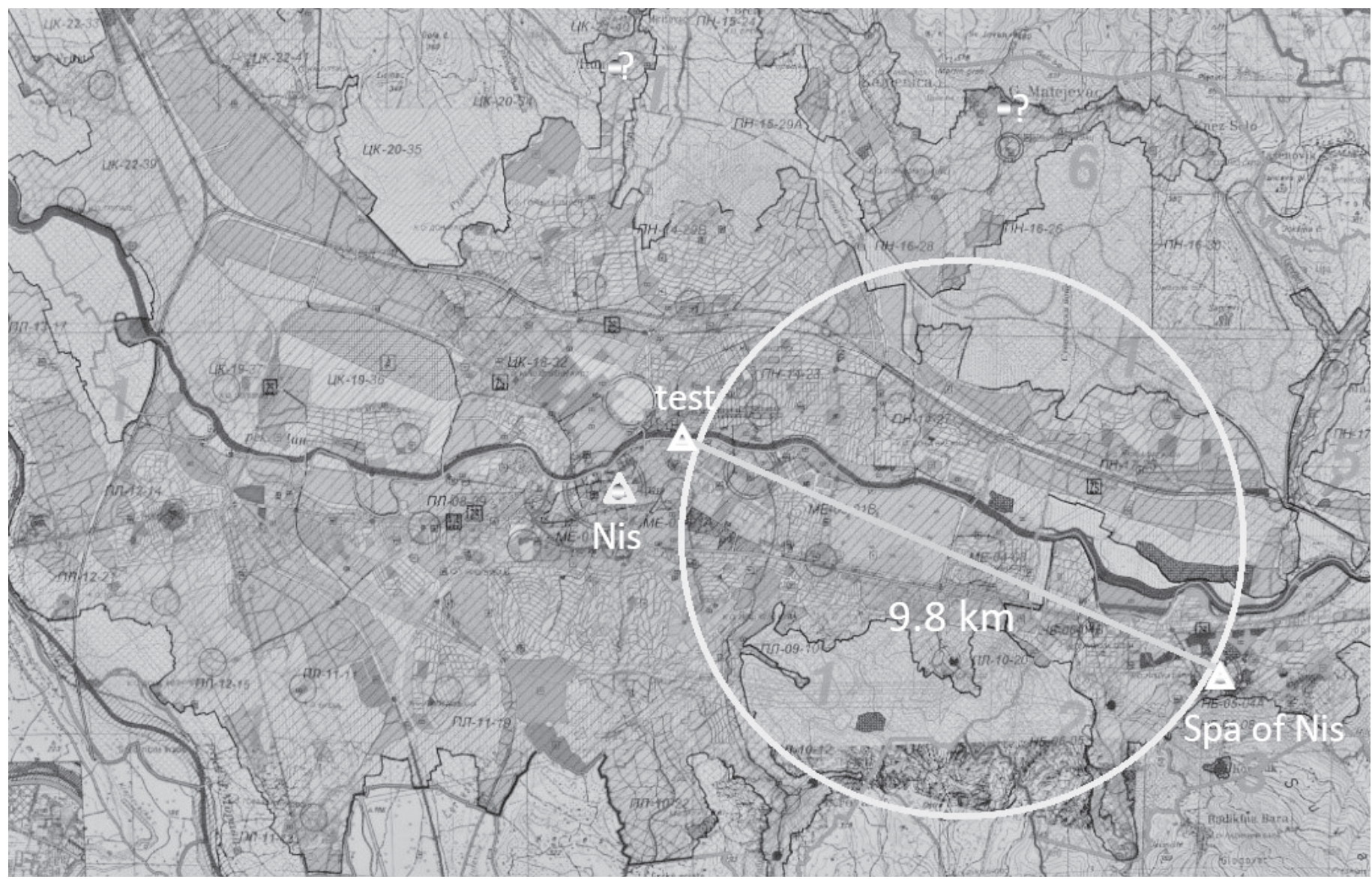

Fig. 2. General Urban Planning document of Nis (GUP 2010-2025), [20], mentions geothermal energy as source of environmental protection very generally [5], official plan. Triangle (left): city centre, Triangle (centre-right): existing geothermal test drilling site, Triangle(right): potential untapped geothermal resources in Spa of Nis, (up): locations with question marks, other GE sources of possible value for city's supply [Figure: A. Jovanović, using [5] and [20]]

purposes or thermal energy gain is insignificant in terms of the overall redistribution of energy use in Serbia. In terms of energy balance of Serbia, the role of geothermal energy is underappreciated. According to $[14,1]$ it is not explored enough, at least not to the extent, when its role as energy source can be determined and position secured within the energy market". The analysis of interviews with an expert in urban and economic development [4], an expert in geology and geothermal energy utilization [2] and an expert in geothermal energy utilization [3], showed the main problem to lie within:

- financing of geothermal projects, research and pilot studies;

- lack of information about geothermal energy leading to the lack of finance for project initiation;

- cultural and socio-economic obstacles that sometimes play greater role in the utilization of geothermal sometimes than those of technical nature.

On the other hand, geothermal energy is one of the cleanest technologies and could significantly reduce the gases at an urban level, especially that of $\mathrm{CO}_{2}, \mathrm{~N}_{2} \mathrm{O}, \mathrm{CH}_{4}, \mathrm{HFC} / \mathrm{PFC} / \mathrm{SF}_{6}$ emissions and other gases [14], [15]. This in turn, allows for a better living environment resulting in better health among the population and better and more livable towns and cities.
The city of Nis has an issue of air pollution. Judging by the results of scientific public safety survey conducted recently [10] there are significant amounts of $\mathrm{SO}, \mathrm{CO}$, dust and other in the city of Nis. According to measurements available to Zivkovic [28], an increase of $\mathrm{CO}_{2}$ emissions is especially notable at the end of the heating season. In addition, a global increase of $\mathrm{CO}_{2}$ emissions from year 1780 is estimated to be at the rate of about $31 \%$ [14]. And about $98 \%$ of the $\mathrm{CO}_{2}$ emissions come from burning of fossil fuels. The rest comes from cement and calk production, uncontrolled forest eradication, burning of waste etc. [14]. As for NOX, the biggest contributor to this pollution is traffic, followed by energy production. Based on the mentioned studies, some of these pollutants are present in Nis, despite the existence of clean energy utilization potentials.

This paper raises the question if geothermal energy as a local resource can help Nis to have more sustainable urban development. A referral to the unutilized geothermal potentials of Nis will be given in the following chapters, to support the argument in planning of Nis in the future (Fig. 2). Another argument for possible utilization of geothermal energy in Nis can be found in its historical use of spas (e.g. Spa of Nis) and heating systems dating back to Roman and Turkish times [10], [11]. 


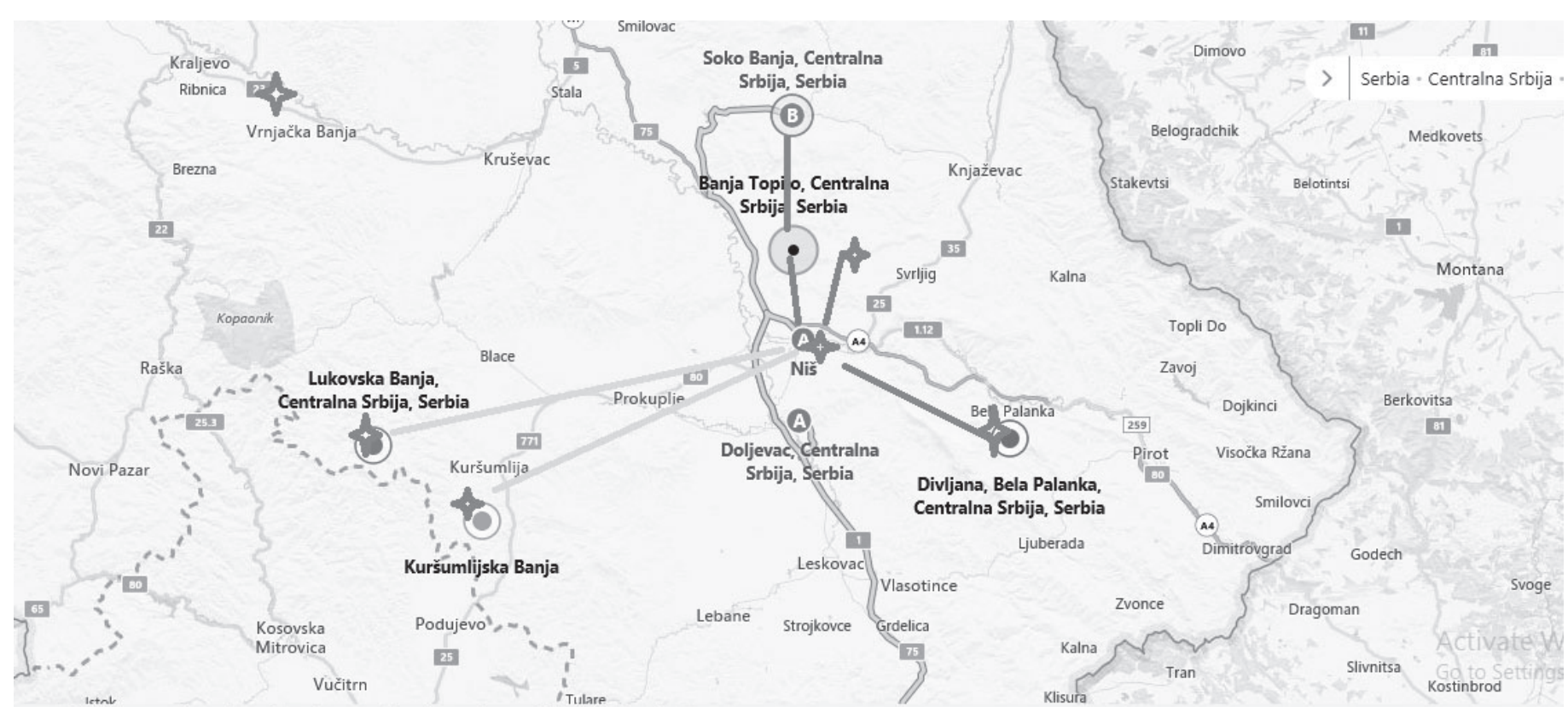

Fig. 3. Regional map of geothermal resources, city of Nis being in the centre, surrounded by Banja Topilo, Sokobanja to the northeast, Popsica and Divljana thermal spring. Further away are Lukovska Spa, Kursumlija spa, Vrnjacka banja. In these locations, geothermal manifestations with low enthalpy have been spotted, in the range of $30-65{ }^{\circ} \mathrm{C}$ and with flowrates from $5 \mathrm{l} / \mathrm{s}$ (Topilo/Kravlje) to $60 \mathrm{l} / \mathrm{s}$ (Lukovska Spa), which can jointly be considered for supplying Nis with heat, making thermal network of towns in SE Serbia and connecting to other neighbouring regions. These resources are most likely important for Nis in the future [Figure: A. Jovanović, based on www.bing.com/maps].

\section{A. Geothermal Potentials in Nis and Their Relation to Planning}

There are a couple of natural warm water springs in the territory of the city of Nis. Mostly known are those in Niska Banja (Spa of Nis), just $11 \mathrm{~km}$ from the city urban core, with temperature of $38^{\circ} \mathrm{C}, 34^{\circ} \mathrm{C}$ and $37^{\circ} \mathrm{C}$ and flow rates of $40 \mathrm{l} / \mathrm{s}, 20 \mathrm{l} / \mathrm{s}$ and $50 \mathrm{l} / \mathrm{s}$, respectively [6, 261-267]. The Spa of Nis had been known for centuries for its geothermal resources. The archaeological findings of Late Antique buildings have been located near the Spa centre. The existence and utilization of geothermal source in the old bath, matching the historical location of the ancient bath in the Spa mentioned in literature, was documented by some archaeological excavations, mentioned by Stevanović $[23,1]$. There is a big layer of modern buildings, hotels, houses and other, which have been built on top of the archaeological findings. Some of them remain uncovered, for sure. Today's urbanity of the spa centre is very much due to the existence of the geothermal resources and the investments made by different governments in the country to make this small spa a place of leisure and balneology (Fig. $4-$ Map of the Spa). It is however, not decided to use geothermal sources for heating purposes other than a local hotel. Firstly, because the temperatures do not seem to be high enough $\left(38^{\circ} \mathrm{C}\right.$ and 29 around $30^{\circ} \mathrm{C}$ ) to be used as district heating resource. All buildings in the urban area of Niska Banja have individual heating, mostly wood, being the cheapest and most commonly found in the area. Individual ownership of housing, sticking to traditional resources and lack of interest in advanced technology in heating are the obstacles present here. Partly, public hotel facilities where water is being used to some extent (via heat pumps) do not have interest in investing in a larger geothermal utilization

system than it is now, as they do not seem to have any interest or lack funds. Furthermore, it seems that the political institutions do not have enough power to implement long-term projects and to invest in district heating with geothermal sources.

Another problem is the insulation of buildings and much needed renovation of buildings in the area. Even if geothermal district heating were applied, the waste of energy due to poor state of buildings would be inevitable.

On the other hand, district heating option, even with shallow geothermal sources seems like a good option, whenever the resource is available at a given rate, even with lower temperatures, since it covers the base loads, which are high and are covered normally by using fossil fuels.

One example of using low enthalpy geothermal energy is district heating in Paris, France. It has been in use since the $14^{\text {th }}$ century when the initial system was installed. Some recent expansions of the system allowed for another 200000 houses to be covered by this form of energy [21]. It contributes to the reduction of $\mathrm{CO}_{2}$ emissions in the metropolitan region of Paris and to better life quality of the urban environment in terms of pollution.

As to Nis, there are at least two known geothermal localities outside the city, one in Miljkovac (Banja Topilo) and the other in Kravlje (Popšica), with some in the suburbs of Gornji Matejevac and Hum within the city limits, according to $[9,22]$. The temperatures there are lower than current temperatures within the rural areas of the city region. They are used for small pools and some for spa (e.g. the spa of Topilo some $20 \mathrm{~km}$ from the city). Other resources are found in Sokobanja (62 km from Nis), Divljana, and further to the south (Fig. 3). 


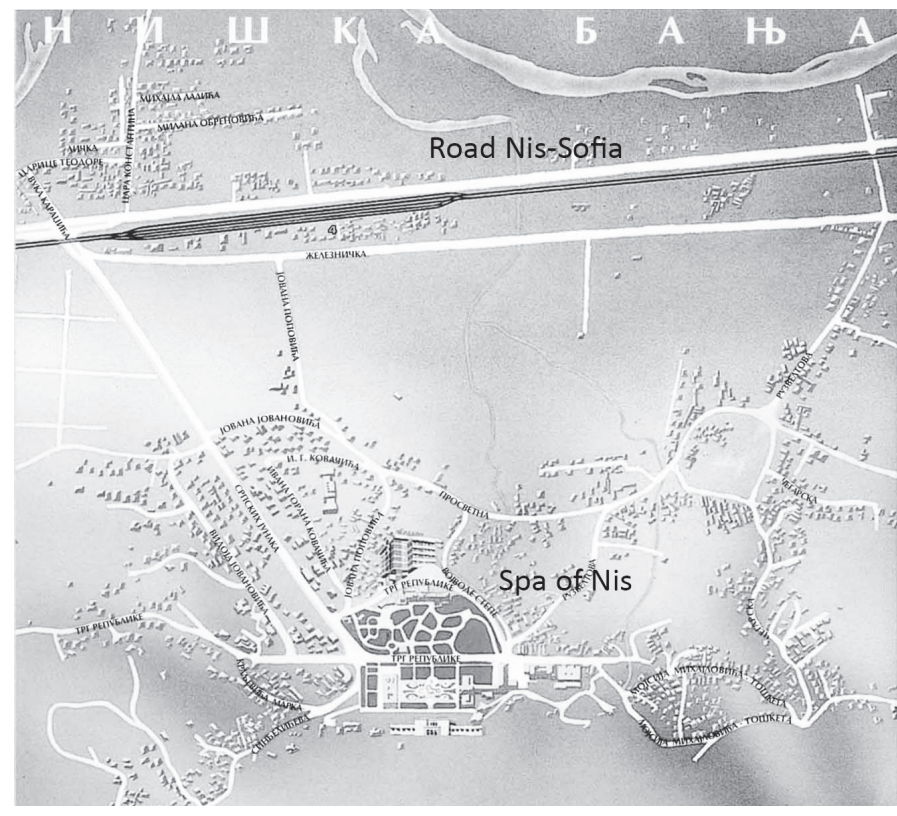

Fig. 4. The map of Spa of Nis with the road Nis-Sofia (upper part) [Figure: Nis Plan Grada, 2014, official calendar].

Their vicinity to the city open a question: whether they could be used more and whether the capacities can support district heating at least in some parts of the city. Possibly the district heating system (referred to as a DHS further in the text) can be localized to a specific campus of buildings, resorts or residential complex as a pilot study for more geothermal use in Nis in the future. Currently, the city of Nis has a system of district heating, based on mazut and gas, approximately equally used in the share of fuels. As for electricity, it is subsidised by the state, therefore many areas use it for heating. It is being produced by burning coal and hydro energy, the first one contributing to greater extent in the share.

The city should have a broader planned set of initiatives such as green city project, that tackle the problem of careful and interconnected consideration of different elements of sustainability in the long run [7].

Another important connection to planning is the fact that geothermal DHS and other GSHP installation initiatives are beneficial if they go hand in hand with refurbishments. According to the scientific reports on the state of buildings in Serbia, the built funds need refurbishments, as most of the buildings have been built before 1990, and some of them lack basic insulation and window installations that would satisfy the standards of energy efficiency [13].

There should be a good reason to invest in a city infrastructure in the long run and this is not easy to achieve. The reasons must be found in a feasibility study that would have to be developed. Theoretically, academia can help with information about the historic connection to geothermal sources and findings and on the role, it had in the past in this region, which should not be forgotten and neglected. Especially, if it initiates new solutions and thinking about the place where it is implemented and can bring financial benefits for the investors and environmental benefits to the citizens. Lastly, it can contribute to branding of the city and therefore to economic development and regional cooperation and planning. Regional planning is important for the role of cities in Europe, as it offers the combination of different resources and capabilities of the cities to develop the network of relations and utilization of the resources among them and to determine the models of their future expansion and cooperation. It also contributes to the polycentrism within the boundaries of the country, which in turn results in less dependence from the central regions, strengthens local initiatives to make further progress in green environment and projects of urban renewal, emphasis on the importance of introducing green infrastructure in the city and lastly, connecting rural-urban concept as part of the concept of sustainable regional development [11].

\section{B. Implications of the Results of Study in Practical Urban Planning of the City}

The city of Nis contains these favourable geological materials in the Eastern part of the city core and Nis Spa especially. In the latter, the natural phenomena of warm water exist for centuries. Here, the aquifer lies within the karstificated calk formations at depths of 500-700 m.

Karstification is the process of turning into Karst. Karts is an area of irregular limestone.

Currently, natural resources at the Spa of Nis are used for supplying a balneology hotel with warm water for treatments, as well as for three heat pumps that work using natural water temperatures. The experts of the Geology and Mining Faculty of the University of Belgrade have determined the capacities of $250 \mathrm{l} / \mathrm{s}$ at the temperatures of $40-50{ }^{\circ} \mathrm{C}$. With this capacity, the hotel capacities of the spa can be doubled and a new water centre can be developed in the nearby auto corridor 10, connecting Sofia and Belgrade $[14,36]$. These geothermal reservoir capacities must be confirmed first. Because there can always occur unexpected phenomena and there is not a single drilling in practice that goes swiftly, without problems. This was confirmed in an interview with a geologist [2] and is likely to be expected in prospective drillings in Nis.

Additional set of data from the project report [14], mentions that the current capacities of the geothermal reservoirs in Nis Spa, are sufficient to make district heating of all hotels, hospitals, balneology institutions and to erect agricultural facilities for crop drying, winter fruit and vegetables. By this project report, the capacities are sufficient for supplying heat to quantities of produce sufficient for export out of city and country limits [14]. Especially, Eastern part of the city, surrounded by Nis spa, contains geothermal reservoirs sufficient for different uses, heating of housing buildings. In the rest of the Nis valley, geothermal reservoirs are favourable mostly for agricultural production and drying of herbs.

Finally, the study from 2010 initiated by JKP Toplane (Public District Heating Company Nis), wanted to address problem of high costs of district heating in Nis. Geothermal deep drilling at the depth of $1200 \mathrm{~m}$ was suggested and elaboration of the project initiated in a study from 2014 [14], [18]. Before that, a study proposing geothermal possibilities of Nis had been made [19]. 


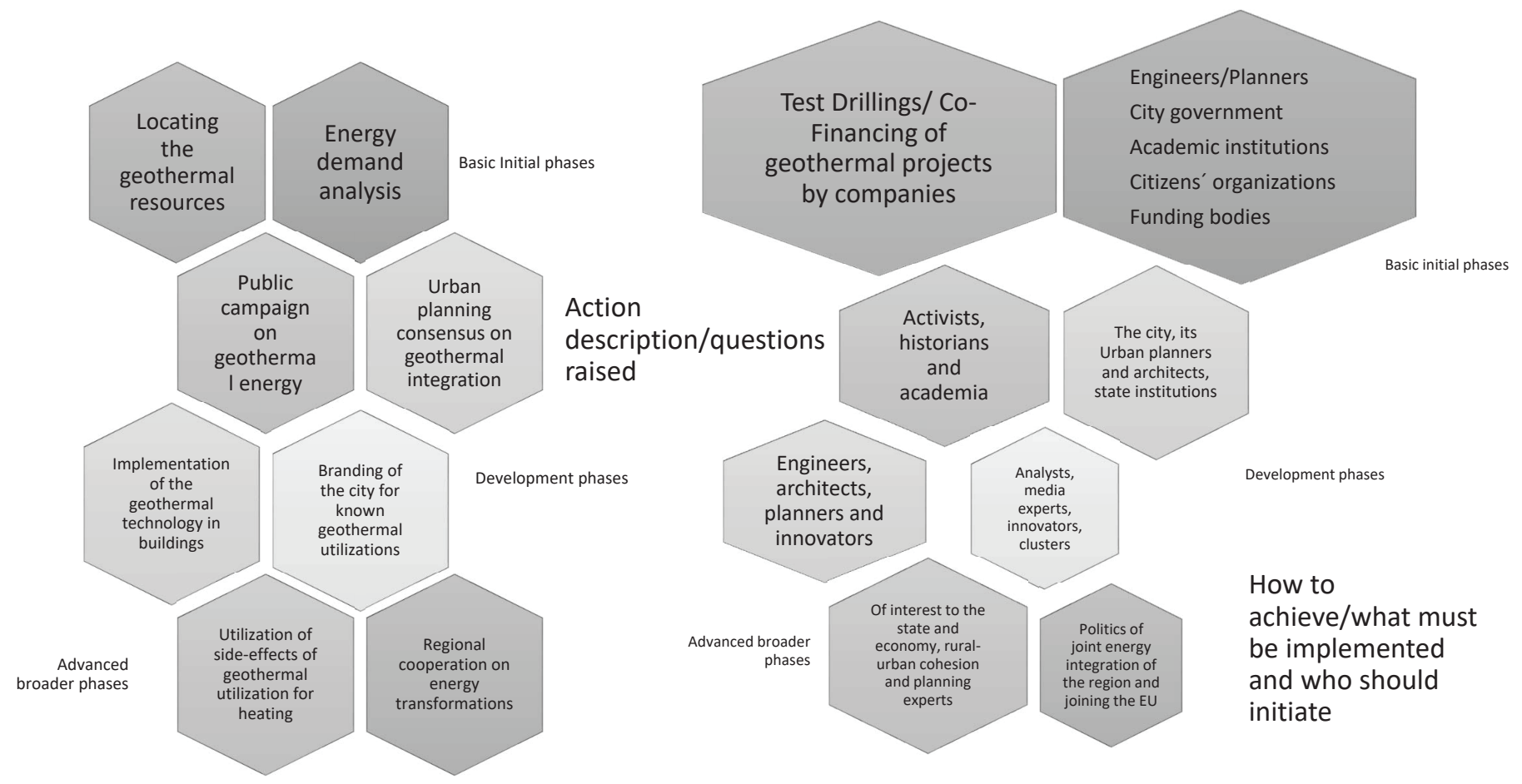

Fig. 5. Phases that need to be done for Nis to get the most out of its geothermal energy utilization perspectives in the long-run, (left) showing actions and (right) showing the stakeholders and the challenge levels (by volume of the hexagon) for each corresponding phase on the left. The outcome of the basic initial phases allows for development and broader phases' development. Probably the Spa of Nis would be one of the most suitable municipalities for a pilot study of a neighborhood [Figure: A. Jovanović].

The official project was made and propositions for drillings and adjoining research activities were announced, supported by the Ministry of technology [14]. However, there would have to be more transparent public information on this on the websites of the heating company and the city, for further advancement of geothermal appreciation in Nis to be made possible.

Also, the project proposal from 2015 suggests that the most favourable area of the city for underground waters utilization in Nis is north-eastern part. The exact location is from the hill Vinik (416 m above Adriatic Sea level) and Baseva glava (328 m above sea level) [14, 31].

The exploitation of the geothermal resources in elaborated within scientific projects which are predominantly in the regions of Northern Serbia and capital region of Belgrade [16]. There are initiatives taken to expand this use to other parts (central and southern Serbia), which do not seem to be enough, as other factors contribute to the lagging of the process of more geothermal utilization in the country, for example bad economic climate, lack of expertise and tax money, among other, which could be better addressed. Geothermal needs backup in Nis.

Like the situation in Nis, an interview with an expert from the City Hall in a post-industrial city of Utica in Northern USA, confirmed that after having done first initial geothermal project, it is easier for the community to accept and believe in the feasibility of renewable technology application in a city [4].
IV. Instead of Conclusions: Urban Planning and Geothermal in Nis - The Next Steps to Be Taken

The Figure outlines the necessary steps if geothermal utilization would be analysed for the benefit of the city and its adjoining areas (Fig. 5).

One of the most important steps than needs to be taken now is to make a pilot study of a city neighbourhood and see if geothermal energy can be sufficient as heating source and to what extent it would be possible. If yes, one should focus more on it. If not, focus should include other renewable energies for long-term urban planning development, where geothermal sources can contribute. Secondly, by public activation, praising of geothermal and its importance for combating the decline of the city, alternatives could be suggested. This is the only way to find sources by the state and/ or companies willing to invest money in test drillings for geothermal waters and confirming their accuracy of temperatures and flow rates available, being essential for the planning for geothermal utilization in Nis. Confirmation of geothermal reservoir capacities is the prerogative for seriously dealing with this local resource in the long-run in Nis. Should other forms of renewable energy be considered more fruitful for Nis (like solar), the confirmation of GE capacities is still to remain important, due to the broader regional picture in dealing with geothermal and energy networks in this part of Europe.

In Nis, the cases of geothermal utilization are very localized and specific for the places where the natural resources were 
known to have existed for a long time, like in Nis spa. Only a portion of this energy coming from ground resources is tapped into and is currently used. Therefore, a more thorough case study on the state level is needed to evaluate the potentials of these spaces and their more efficient use of geothermal resources. In conclusion, there are substantial capacities for the utilization of geothermal water in Nis, with diverse capacities of the geothermal resources. This allows for endless possibilities and different implications for each part of the city and beyond.

One other aspect that is underappreciated is its (geothermal) connection to urban planning and especially to the development of neighbourhoods and urbanity where there would be the need for this in the future. Planning of cities with local resources will gain in interest, especially within the process of constant increase of urban territories in the whole country in the future, as part of the global trend of migrations from rural towards urban.

In this way, urbanism can play a role in the development of at least one part of the city in the future of urban planning in Nis. By given expert opinions elaborated in the paper, quite possibly geothermal utilization can play a role in the development of its surroundings, in the context of regional development and rural-urban cohesion as well. This is, however, an open question, how can this be advocated best?

Finally, more advanced geothermal utilization can affect the health and environmental issues the city and its inhabitants are facing, which arise by using fossil fuels for heating, such as natural gas and mazut. Parallel to this, by making neighbourhoods more pedestrian-accessible, less car dependent and designing buildings and blocks with passive house principles, some of the problems of Nis can be solved, even if just in the 'long-run'.

Urban planning situation in the city can benefit from GE utilization because it will include local resources in the early stages of further urban developments. Geothermal energy utilization and its effects on the city are a matter of long lasting interest. This way it can support future practical needs of the city, its engineers, planners and future dwellers. Beyond this, geothermal utilization can play a role in the development of its surroundings, in the context of local cooperation with other regions in SEE and rural-urban cohesion of the city and its surrounding villages.

It is easy for countries with strong economies to pursue transition to geothermally-based systems. For those which are not, the greatest challenge is to persuade the population to invest a great share of its tax money for geothermal drillings for cities and towns. Turning to historical references and praising the cultural awareness of geothermal energy is the greatest asset in the pursuit for greater energy independence of cities in the region of South East Europe, such as Nis. Once made, these pilot studies could be 'recycled' to offer development models for this part of Europe, in terms of renewable energy utilization as a planning tool.

\section{REFERENCES:}

1. Arhus Centar Subotica [online]. Zelena Srbija [cited 20.11.2017]. http:/ zelenasrbija.rs/srbija/2897-neiskorien-veliki-potencijal-u-geotermalnim-izvorima? $\mathrm{fb}$ action $\mathrm{ids}=425717560820592 \& \mathrm{fb}$ action types $=$ og.likes $\& \mathrm{fb}$ source $=$ aggregation $\& \mathrm{fb}$ aggregation $\mathrm{id}=288 \overline{38} 1481 \overline{23} 7582$
2. Expert in geology and geothermal energy utilization, based in Austria, interview by A. Jovanović. Graz, September 2015.

3. Expert in geothermal energy utilization, based in Serbia, interview by A. Jovanović. Nis, October 23, 2015.

4. Expert in urban and economic development, Utica, City Hall, interview by A. Jovanović. Utica, November 27, 2016.

5. Expert in urban planning, based in Nis, interview by A. Jovanović. Nis, November 23, 2015.

6. Filipović, B. Mineralne, termalne i termomineralne vode Srbije. Vrnjacka Banja, Beograd: Udruzenje banjskih i klimatskih mesta/ Institut za Hidrogeologiju RGF Beograd, 2004. 278 p.

7. Ecocity, Book 2: How to make it happen [P. Gaffron, G. Huismans, F. Skala, ed.]. Deliverable of the project, Vienna: Facultas Verlags- und Buchhandels AG, 2008. $82 \mathrm{p}$

8. Gajić, B. Uspešno bavljenje energetskom efikasnošću na lokalnom nivou - primer grada Niša, POLIS, casopis za javnu politiku, 2013, Vol. 6 , pp. 64-67. ISSN 2334-637X

9. Grupa autora [D. Milić, urednik], Istorija Nisa, Vol. 1. Nis: Gradina, 1983 $373 \mathrm{p}$.

10. Institut za javno zdravlje Niš, Izveštaj o kvalitetu vazduha na teritoriji grada nisa za period maj 2007- april 2008. Nis: Gradska Uprava Grada Niša, Sekretarijat za zaštitu životne sredine, 2017. 28 p.

11. Jovanović, A. Urban planning and renewable energy- experts' opinions and their contribution to the development of urban strategies in the Serbian city of Nis. IX naučno - stručna konferencija sa međunarodnim učešćem: saobraćajni $i$ infrastrukturni sistemi, prirodni resursi $i$ zaštita životne sredine, Beograd: Union of Engineers of Belgrade. 2017. pp. 184-193,

12. Jovanović, A., Cekić, N. Geothermal Energy Use in Terms of a More Bal anced \& Sustainable Urban - Rural Development of Southeast Serbia, with Focus on Nis Region. Arhitektura i Urbanizam, Issue 45, 2017, ISSN: $2217-$ 8074 , IAUS, Beograd, in print.

13. Jovanović-Popović, M., Ignjatović, D. Strukturiranje gradjevinskog fonda stambenih zgrada Srbije sa aspekta energetske efikasnosti-nacionalna tipologija. POLIS, casopis za javnu politiku, 2013, Vol. 6, pp. 31-38. ISSN 2334-637X

14. Lazić, M., Pavličić, S., Kljajić, Z. Project of the deep geothermal drilling $I H B N-1$ for the purpose of the exploitation of geothermal waters. Belgrade: University of Belgrade, Faculty of Mining and Geology; Geo inzenjering BGP Beograd, 2015. $88 \mathrm{p}$

15. Malafeh, S., Sharp, B. Geothermal Development : Challenges in a Multiple Access Scenario. PROCEEDINGS, Thirty-Ninth Workshop on Geothermal Reservoir Engineering, Stanford University, Stanford, California, February 24-26, 2014. pp. 1-11 [cited 25.12.2017]. https://pangea.stanford. edu/ERE/db/IGAstandard/record_detail.php?id=19856

16. Milenić, D., Vranješ, A. Naučnā studija : geotermalni potencijal teritorije AP Vojvodine, Scientific Study. Belgrade: Univerzitet u Beogradu, Rudarsko-geoloski fakultet, 2015. 489 p.

17. Micić-Maksin, M. Problems and possibilities for steering urban sprawl in Serbia, Urban Sprawl in Serbia. 44th ISOCARP Congress 2008, proceedings. Dalian, China, ISOCARP, Knowledge for better cities, 2008.

18. Petković, B., Radojević, A. Studija opravdanosti izgradnje bunara dubine $1200 \mathrm{~m}$ za iskoriscavanje geotermalnih potencijala podzemne vode $u$ Toplani Krivi Vir, JKP Gradska Toplana, Nis. Nis: JKP Gradske Toplane, international project documentation, 2014

19. Perić J., Milivojević M., Simić M. Javna anketa Niš : istraživanje i korišćenje geotermalne energije u Niškoj kotlini kao jedan od faktora razvoja grada do 2000. godine i za 21. Vek. Survey. Nis: Direkcija za urbanizam i izgradnju i rekonstrukciju Niša, OOUR Zavod za Urbanizam, 1989.

20. Ragnarsson, Á. Utilization of geothermal energy in Iceland, Proceedings of International Geothermal Conference, Reykjavik, Geothermal Association of Iceland, September 2003, pp. 39-45.

21. Richter, A. New geothermal heating plant started operations in Paris, France, March 31, 2017 [online]. Thing Geoenergy [cited 20.11.2017]. http://www.thinkgeoenergy.com/new-geothermal-heating-plant-started-operations-in-paris-france/

22. Stanković, M., Segović, D., Maksić, M., Ilić, S., Bogdanović, V., Micić, S., Janković, D., Stojanović, V., Nikolić, J., Radivojević, D., Milosavljević, M., Stojanović, D., Antić, P., Petković, M., Golubović, Z. GUP Grada Nisa, General urban planning document 2010-2025. Niš: City of Niš. 2011. 201 p.

23. Stevanovic, S. Niska banja, Štamparija Drag. Gregorića, Beograd, 1941 $50 \mathrm{p}$.

24. Todorović, M., Ličina, D. Parametric Analysis and Thermodynamic Limits of Solar Assisted Geothermal Co-And Tri-Generation Systems. ASHRAE Transactions, Volume 117, Part 1, 2011. 10 p.

25. Tulinius, H., Ingason, K., Nikolic, N. Report on Task A4 : Pre-feasilibility study Bogatic,. Promotion of Renewable Energy Sources and Energy Efficiency Republic of Serbia, Brussels/ Belgrade: EU/ Eptisa servicios de ingeneria, 2012

26. Vasović, D., Radulović, G. Energetska efikasnost : primer Grada Beograda, POLIS, casopis za javnu politiku, 2013, Vol. 6, pp. 39-45. ISSN 2334-637X 
27. Weber, T., Guttikonda, A., Mc Crone C., Scott N., Tester J., Cloutier, S. Sustainable Communities for Revitalizing and Transforming New York, White paper, Ithaca, Cornell University, 2013, 48 p.

28. Živković, P. M., Tomić, M. A., Ilić, G. S., Vukić, M. V., Stevanović, Ž. Ž. Specific approach for continuous air quality monitoring. Hemijska Industrija 66, Issue 1, 2012. pp. 85-93. https://doi.org/10.2298; HEMIND110525066Z

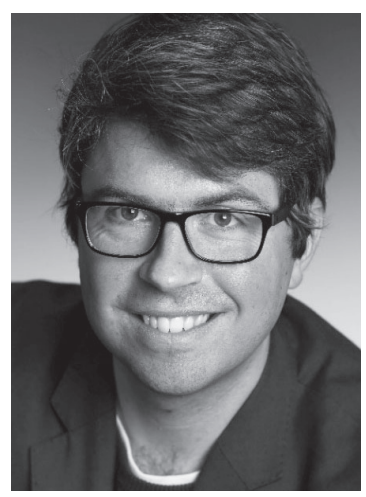

Aleksandar Jovanović, d.i.a. (DI), has graduated from the University of Nis, Serbia in 2006 with an awarded graduation project of a student dormitory in Nis. He has worked as an architectural engineer for architectural offices Marger doo, Tanos Architektur GmbH and Urbanist Project doo, as a junior-associate on main projects and design studies of architectural design.

$\mathrm{He}$ is a PhD student in architecture at TU Graz and made a guest research visit to Cornell Univerity at their Energy Institute in 2016/2017, where he worked on revitalization projects of NYS cities to become renewable-energy-based-communities. He is interested in geothermal energy, the role of daylighting, passive urban design and the role of history in transition towards more sustainable planning of cities and urban design.

\section{Contact Data}

Aleksandar Jovanović

TU Graz, Faculty of architecture, Doctoral school Architektur

Address: Rechbauerstrasse 12, $8010 \mathrm{Graz}$, Austria

E-mail address: sasha80nish@yahoo.com 